\title{
Some Churches Dedicated to the Holy Wisdom and their Sunrise Orientation
}

\author{
Amelia Carolina Sparavigna ${ }^{1}$ and Lidia Dastrù ${ }^{2}$ \\ ${ }^{1}$ Department of Applied Science and Technology, Politecnico di Torino, Italy \\ ${ }^{2}$ Ricercatrice Indipendente, Torino, Italy
}

Here we discuss the orientation of some churches dedicated to Hagia Sophia, the Holy Wisdom. We can see that four of them have alignment along the direction of the sunrise on solstices (one of the churches is Hagia Sophia in Constantinople). Our discussion focuses, in particular, on alignments of the churches with respect to the decumani of the town in which we find them, in the case the town had a planning of Roman origin (Constantinople, Thessaloniki and Sofia). For Hagia Sophia in Nicaea, we consider its Hellenistic grid-plan with its streets, the plateiai, corresponding to the Roman decumani.

Submitted HAL, April 8, 2018.

The Holy Wisdom, in Greek Hagia Sophia, is a concept identified by the theology with the Son of God. For this reason, throughout the Orthodox world in particular, we can find several churches dedicated to the Holy Wisdom. These churches have as their model the basilica of Constantinople, which is simply known as Hagia Sophia [1]. The extant building dates to the 6th century. As explained in [2], we find dedication of some churches to the Holy Wisdom also in Italy, in the case of churches built prior to the Great Schism, the Schism of 1054 that separated the Roman Catholic Church and the Eastern Orthodox churches.

Near-contemporary to the basilica in Constantinople, we have Saint Sofia in Sofia, Bulgaria. In Thessaloniki, Greece, a church dedicated to Hagia Sofia was built in the 8th century. Moreover, we find Santa Sofia in Benevento, built in the 8th century too, and Santa Sofia in Venice of the 9th century. Of course, churches dedicated to Holy Wisdom have to be distinguished from churches dedicated to the martyr Sophia of Rome, or to one of the other saints with this name. 
Here we will focus our discussion on the orientation of the churches dedicated to the Holy Wisdom, built before the 10th century. We can see that they are aligned along the direction of the sunrise, with their apses on the eastern part of the church. Hagia Sophia in Constantinople and Thessaloniki are oriented to the sunrise on winter solstice, whereas Santa Sofia in Venice and Benevento are oriented to the sunrise on the summer solstice. We will discuss in particular the alignment of the churches in Constantinople, Thessaloniki and Sofia, with respect to the decumanus of their towns, which had a roman origin and consequently a roman town-planning based on a regular grid of streets. For the analysis Hagia Sophia in Nicaea, we consider its hellenistic grid-plan with its streets, the plateiai, corresponding to the roman decumani.

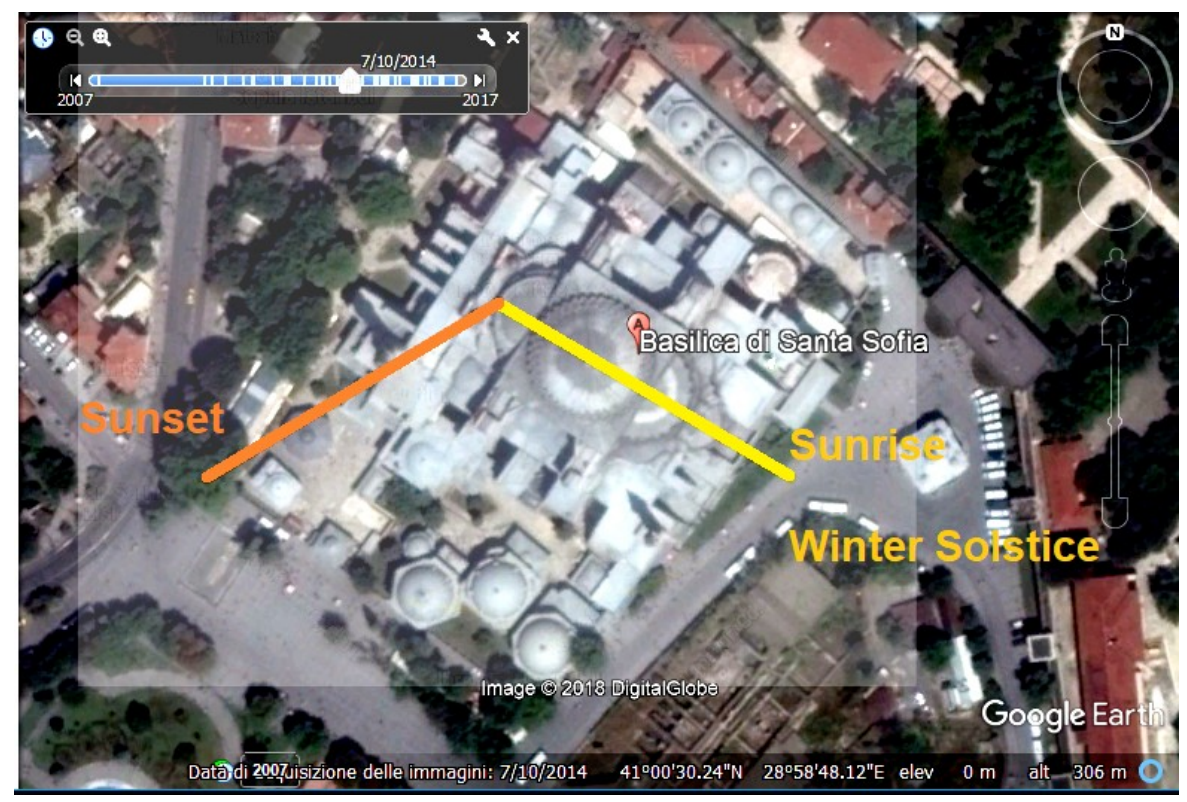

Figure 1: Hagia Sophia in Constantinople and the direction of sunrise on winter solstice.

\section{Constantinople}

As explained in [3], a book which is discussing Hagia Sophia in Constantinople, the influx of light into its interior is directly dependent on the orientation of the building in relation to the sun. In [3], it is stressed that the basilica has its longitudinal axis aligned along the azimuth of the sunrise on the shortest day of the year (winter solstice). 


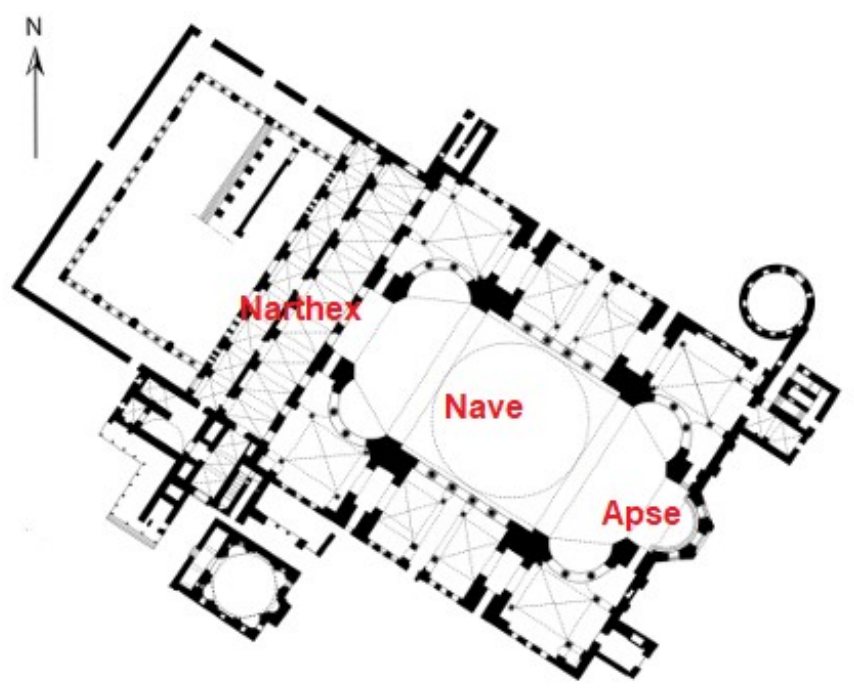

Figure 2: Plan of the church (Courtesy Marsyas for Wikipedia français, image rotated and added names).

Actually, using software such as sollumis.com, suncalc.net or suncalc.org, which are giving the directions of sunrise and sunset for any day of the year on the satellite images or maps of Google Earth, we can find that Hagia Sophia is aligned along the sunrise direction on winter solstice. With the directions of sunrise and sunset given in the Figure 1 , we can see the alignment mentioned in [3]. Let us note that the apse is in the eastern part of the church (Figure 2).

As we can read in [4], Pliny the Elder told in his Natural History that the first known settlement on the site of Constantinople was Lygos of Thracian origin. The site was abandoned by the time some Greek settlers from Megara founded Byzantium in around $657 \mathrm{BC}$. The founding myth of the town tells that the settlement was named after Byzas, the leader of the Megarian colonists. The city was briefly renamed Augusta Antonina in the early 3rd century by the Emperor Septimius Severus (193-211) [4], who razed the city to the ground in $196 \mathrm{AD}$. However, this name was quickly abandoned, reverting to Byzantium.

The town became Constantinople after its re-foundation under Roman emperor Constantine I, who transferred there the capital of the Roman Empire from Rome, in 330 AD. The new capital was officially designated as Nova Roma, the New Rome. During this time the city was also known as the Second Rome. After the fall of the Roman Empire of the West, the city became the unique capital of the Roman Empire and its wealth and influence grew steadily. Actually, Constantinople became the largest 
and wealthiest city in Europe during the 4th-13th centuries and also a center of culture and education of the Mediterranean basin. It was also defined the Megalopolis of the world.

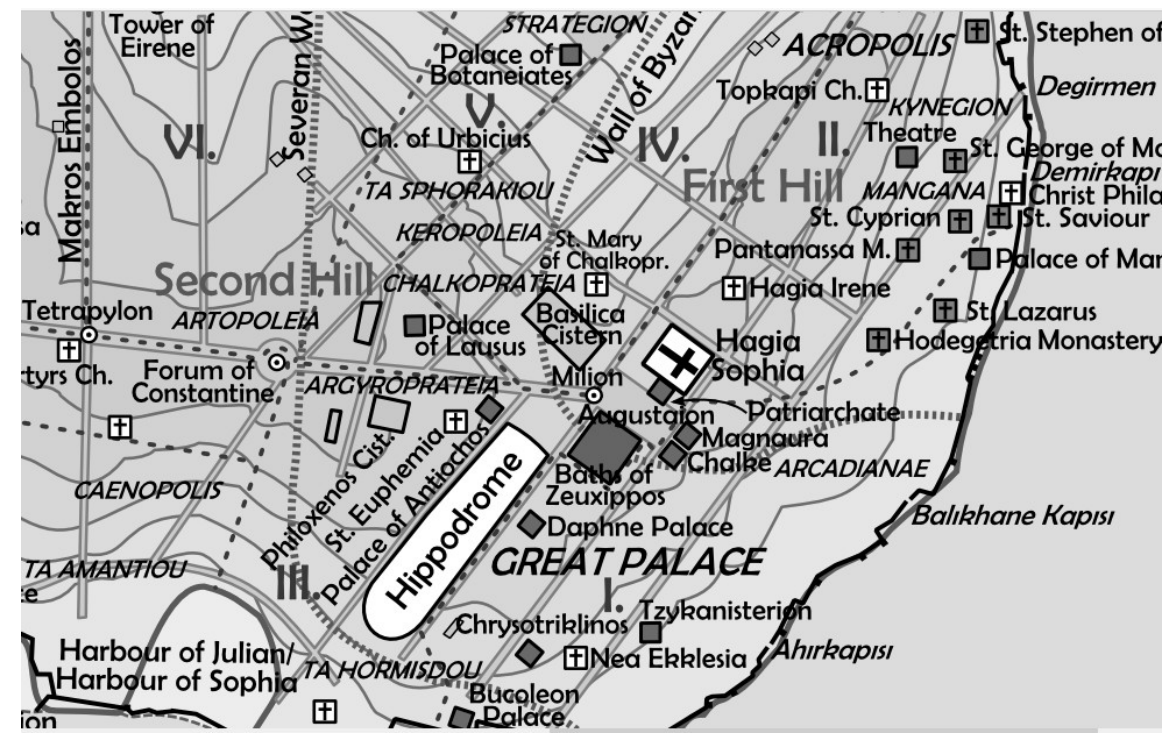

Figure 3: Topographical map of Constantinople during the Byzantine period (Courtesy Cplakidas and Wikipedia).

Thanks to Wikipedia, https://it.wikipedia.org/wiki/Costantinopoli, and user Cplakidas, we can see a topographical map of Constantinople during the Byzantine period, a part of which is given in the Figure 3. The main source of the map is [5] and the road network and other details are based on Dumbarton Oaks Papers 54 [6]. Cplakidas has also used data on churches, especially unidentified ones, from the New York University's The Byzantine Churches of Istanbul project.

We can see from the Figure 3, that Hagia Sophia is aligned along streets that are intersecting each others at right angles. This part of the town had therefore the typical chess-board Roman planning, based on the main streets, decumani and kardines, crossing each other at right angles. Then, it means the following: it is possible that it was the decumani of Constantinople that were aligned along the sunrise on winter solstice, not the church. As we will see in the following, another case exists where the church of Hagia Sophia is aligned along the sunrise on winter solstice like the decumanus of the town. It is the case of Thessaloniki. 


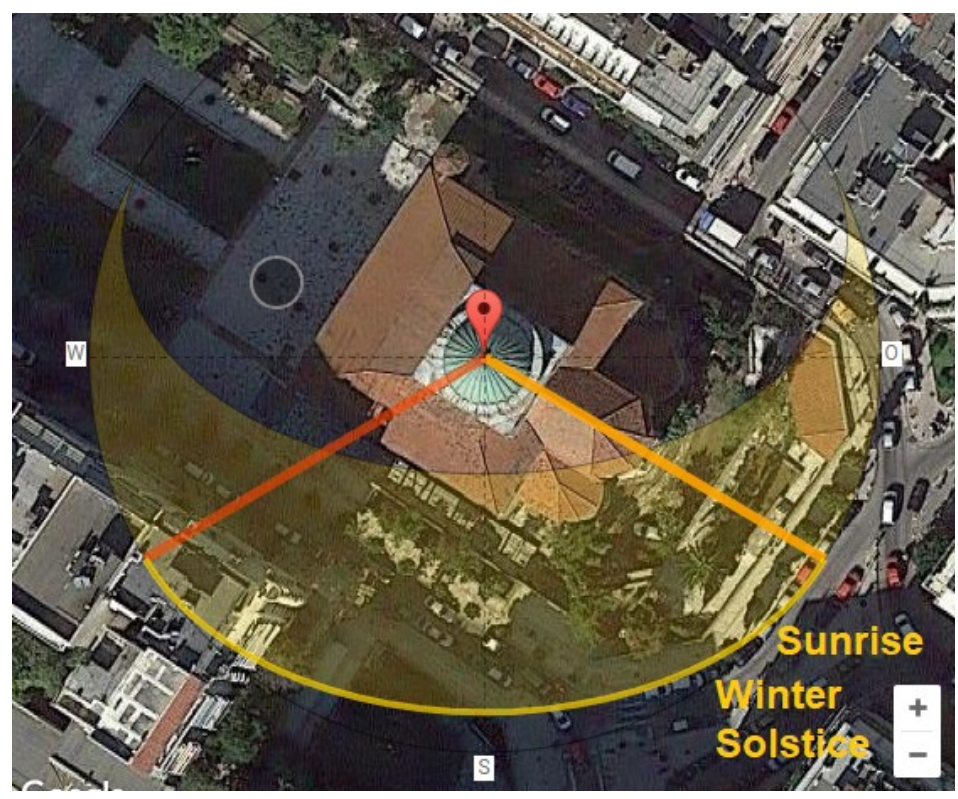

Figure 4: Hagia Sophia in Thessaloniki. The church is aligned along the sunrise on the winter solstice, like the decumanus of the Roman town. In the image, we can see the directions of sunrise and sunset, given by software suncalc.org. The yellow curved line represents the apparent motion of the sun in the sky. The church has the apse in its eastern part, the entrance is on the western side, as we can see from the Figure 5.

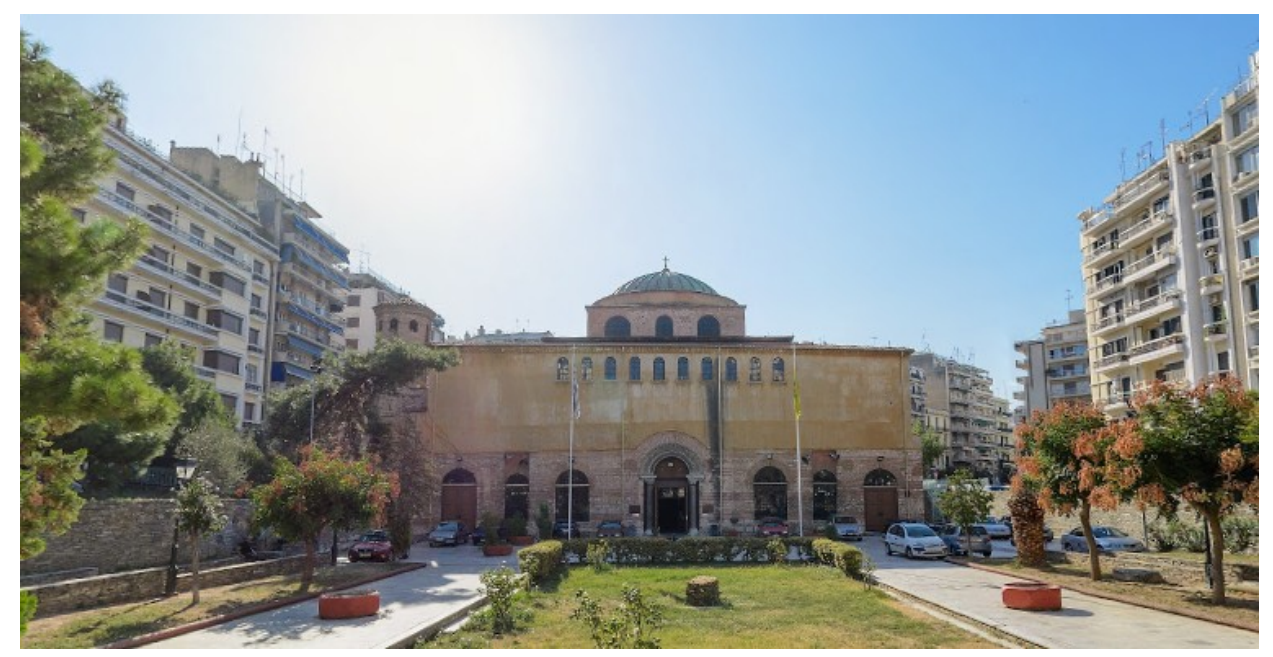

Figure 5: Hagia Sophia of Thessaloniki seen in Street View (Courtesy Google Earth).

\section{Thessaloniki}

As previously told, Hagia Sofia in Thessaloniki was built in the 8th century having as its model the basilica in Constantinople. Also in this case, the orientation of the church is to the sunrise on the winter solstice. In the Figure 4, using suncalc.org, we see alignment of the main axis of the church along the azimuth of the sunrise (the entrance 
is in the western part of the church, Figure 5). This alignment was proposed in [7], where it is also discussed that the church had its axis fixed by the ancient decumanus of the town. It means that this decumanus had the same solstice alignment too.

For what concerns the town, let us remember that Thessaloniki was founded around 315 $\mathrm{BC}$ by the Macedon King Cassander. After the fall of the kingdom of Macedonia, in 148 BC Thessaloniki became the capital of the Roman province of Macedonia. Later, the town became the capital of all the Greek provinces of the Roman Empire, besides being an important trade center on the Via Egnatia, the road that was linking Rome, through Dyrrhachium (Durazzo in Italian), with Byzantium [8]. In Thessaloniki, the Via Egnatia was also the largest of the decumani, that is, the main road of the town.

In [7], the author studied the orientation of 32 churches in Thessaloniki, which were built from the 4 th to the 20 th century. The work investigated a possible astronomical alignment to "any significant solar date or to the date of the patron saint's festival". The author found that the majority of buildings (16) follow the city grid, which is fixed by the Roman decumanus. "Buildings outside the Roman city have a variety of orientations. There are 7 cases of alignment on the patron's saint day (5 positive and 2 indecisive). However, the alignment may be to the sunrise (3) or to the byzantine Third Hour (4), the time the Divine Liturgy reaches its climax" [7]. In [7], the author concluded that the analysis of the churches in Thessaloniki is fundamental for the study of the orientation of byzantine churches in general, "as it points to multiple solutions to the problem of the orientation towards the sunrise on patron saint's feast day".

We have seen that two churches dedicated to Hagia Sophia are oriented to the sunrise on the winter solstice. However, it is probable that these churches had been constrained to this alignment, because the places where they were built had the streets oriented to this specific sunrise. Actually, an alignment of the decumani to the sunrise on solstices is exhibited by several Roman towns [9-16].

In general, as discussed in [17-24], the Romans had a method of land surveying, known as centuriation or limitation, which was based on a regular grid of streets. The main streets are known as decumanus and kardo. In the Latin literature on surveying, it is told that the decumanus maximus, the main decumanus, was oriented towards the sunrise on the day of the foundation or on a date of specific importance for the town [17]. The kardo maximus was fixed perpendicular to the decumanus, the two streets dividing the town in four main parts. Other parallel decumani and kardines were creating the 
"insulae", the blocks of the town. For what concerns the orientation of the centuriation, we have to note that some scholars [24] assume that it was mainly dictated by the local environment, and not by a ritual intention based on the apparent motion of the sun.

\section{Sofia}

As told in [25], the town was originally a Thracian settlement, named Serdica or Sardica. For a short period, during the 4th century BC, the town was under the domain of Philip and his son Alexander the Great. Around 29 BC, Sofia was conquered by the Romans, and during the reign of Emperor Trajan (98-117) was renamed Ulpia Serdica (the emperor was from the gens Ulpia). When Diocletian divided the province of Dacia into Dacia Ripensis - that is on the banks of River Danube - and Dacia Mediterranea, Serdica became the capital of Dacia Mediterranea. In 311, in Serdica was issued the Edict of Toleration by Galerius, which was officially ending the persecution of Christianity. Serdica subsequently expanded for a century and a half, becoming also the "Rome" of Constantine the Great. In 343 AD, the Council of Sardica was held in the city, in a church located where the Church of Saint Sofia was later built. The city was destroyed by the Huns in 447, but was rebuilt by Byzantine Emperor Justinian and renamed Triaditsa.

The town remained under Byzantine dominion until 809. Then it became part of the First Bulgarian Empire during the reign of Khan Krum in 809, known by the Bulgarian name Sredets. The city fell again under the control of the Byzantine Empire in 1018, but in 1191 it was once again under the rule of the restored Bulgarian Empire.

The town was renamed Sofia in 1376, after the Church of Saint Sofia [26]. This church is the second oldest church in the town, the oldest one being the Church of St. George, a red brick rotunda built at a time when Sofia was the residence of emperors Galerius and Constantine the Great. The church of Saint Sofia was built on the site of several earlier churches. This was a place of worship dating back to the Roman period, during which it was the necropolis of the Roman Serdica [26]. "The basic cross design of the present basilica ... is believed to be the fifth structure to be constructed on the site and was built during the reign of Byzantine Emperor Justinian I in the middle of the 6th century (527565). It is thus a contemporary of the better-known Hagia Sophia church in Constantinople. ... Because Saint Sophia represents Holy Wisdom, icons within the 
church depict Sophia as Christ Emmanuel, a young figure of Christ seated on a rainbow" [26].

In Saint Sofia we find again a church which could have been oriented along the direction of the streets of a Roman town. Therefore, let us consider the church and the layout of the Roman Serdica. To determine the direction of the decumanus of Ulpia Serdica, let us use Ref.27 and the map shown in it. By means of Google Earth, we can mark the cornes and a gate of town (see the Figure 6). We can measure the angle of the decumanus and the angle of the Church with respect to the East direction: we obtain 12.5 degrees for the decumanus and 11.5 degrees for the Church. Using suncalc.org we can tell that the church of Saint Sophia has an alignement which can be that of the rising sun at the beginning of March (or middle of October). However, this could be also the direction of a road which was the prolongation of the decumanus of Ulpia Serdica. And that the decumanus was alignned to the sunrise on the beginning of March (or middle of October).
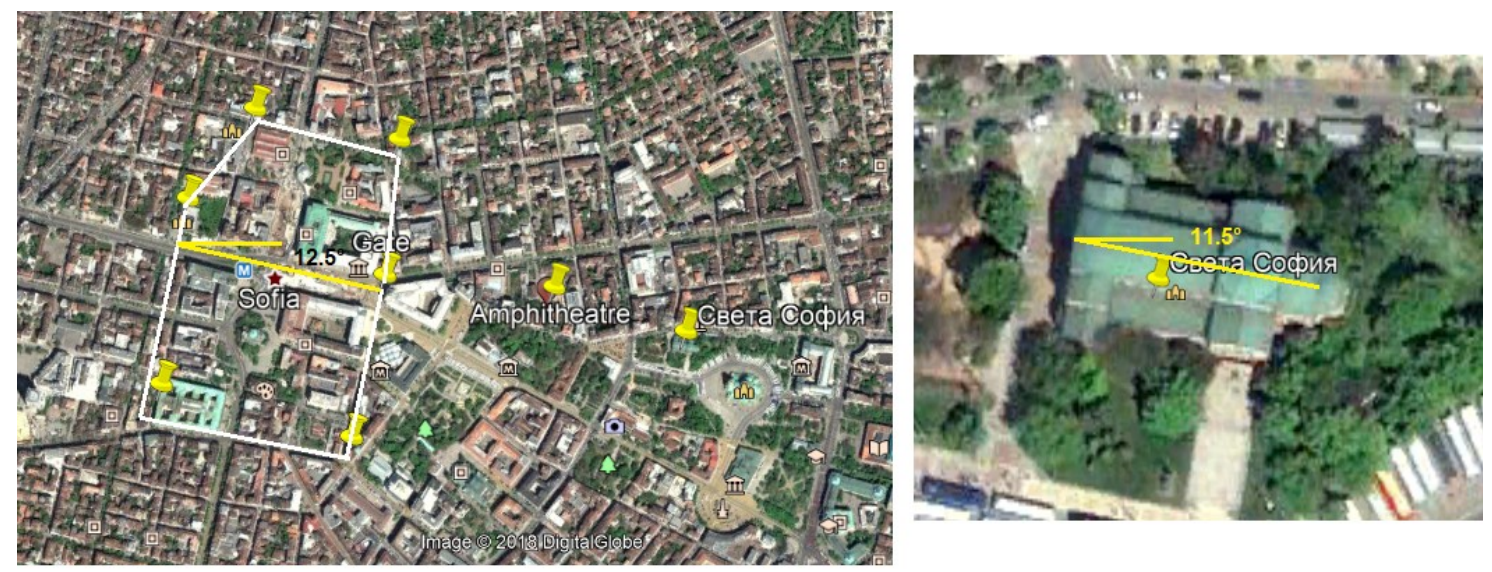

Figure 6: Ulpia Serdica in the modern Sofia. The location of the church of Saint Sofia is marked by the most right pin. On the right, the orientation of the church.

We have seen that in the case of Constantinople, Thessaloniki and Sofia, the churches of the Holy Wisdom are aligned according to the sunrise, but also according to the layout of the corresponding Roman towns. As told before, ancient Latin literature on the roman surveying method tells that the Romans used to orient the planning of their new settlements with a solar orientation [17-19]. As a consequence, in the orientation of churches to the sunrise we can find a pursuance of Roman traditions, besides a symbolic 
orientation to the "cosmic sign of the rising sun which symbolizes the universality of God" [28].

For what concerns the other two churches of the Balkan region dedicated to Hagia Sophia and mentioned by [2], that is those in Nesebar and Ohrid, they were built in the 9th century. Both have an orientation which can be according to the sunrise on the first of March (or middle of October) for the church in Nesebar (Figure 7), and on 7 of April (or the first of September) for the church in Ohrid (Figure 8). Dates are given according to a local astronomical horizon.

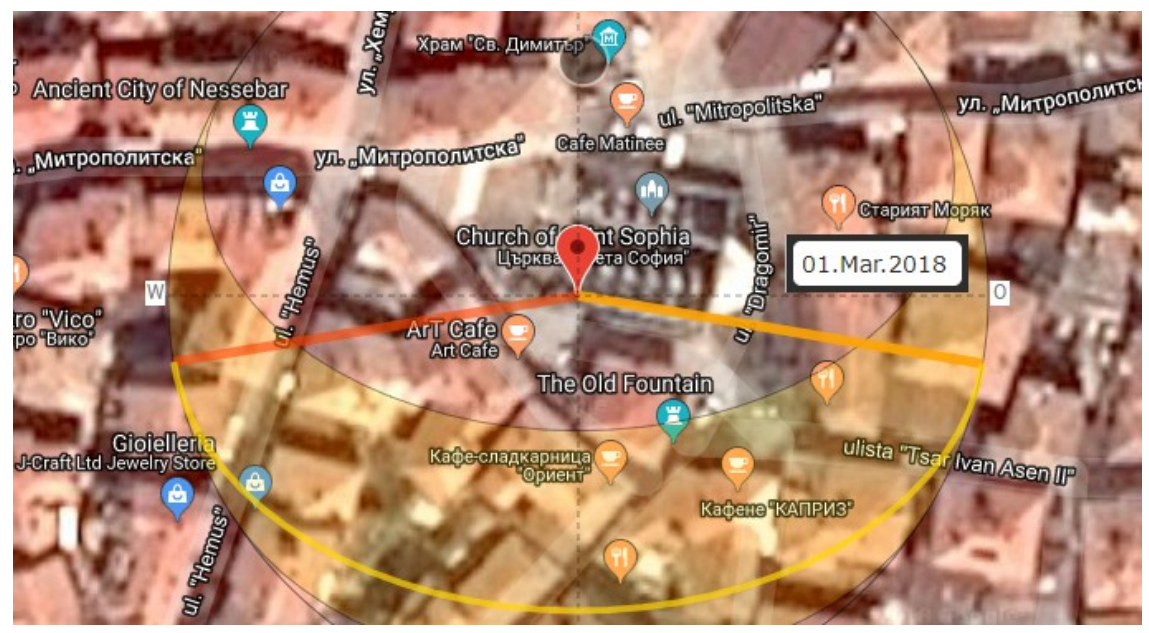

Figure 7: The church dedicated to Hagia Sophia in Nesebar is oriented to the sunrise on the First of March (or middle of October).

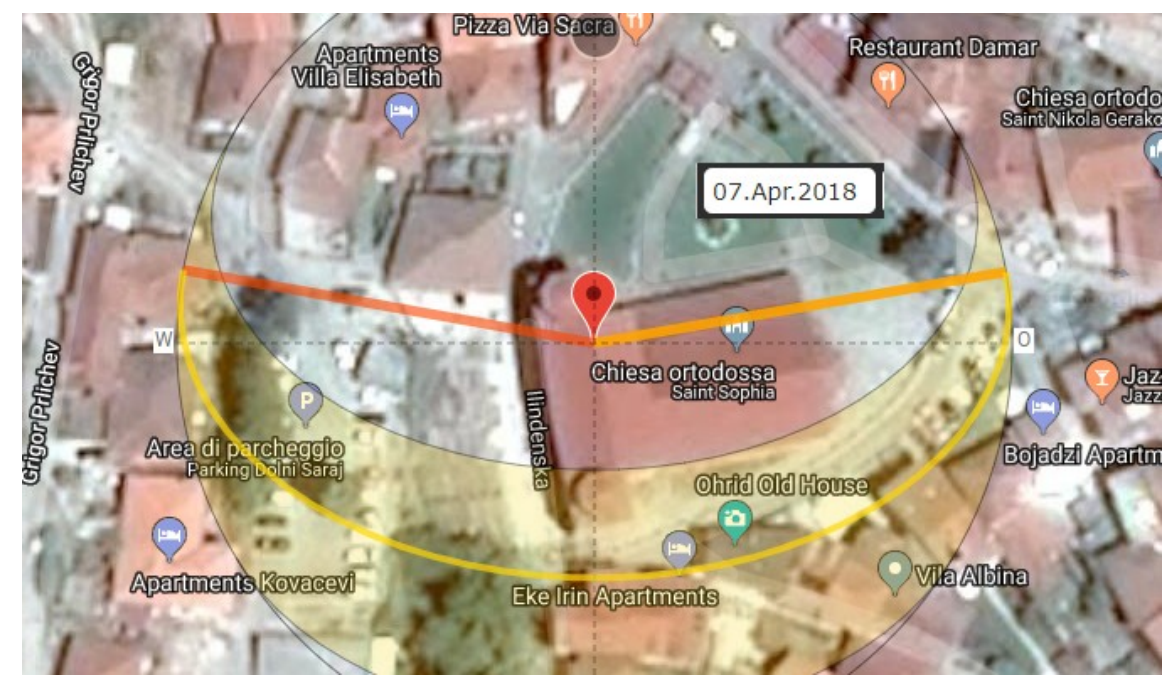

Figure 8: The church in Ohrid is oriented to the sunrise on the 7 of April (or first of September). Ohrid was located along the Via Egnatia. 


\section{Nicaea}

The Nicaea (or Nicea), in northwestern Anatolia, is mainly known in the history of the Christian Church as the site of the First and Second Councils of Nicaea. The ancient town is located within the modern İznik. As told in [29], the place is said to have been colonized by Bottiaeans or by soldiers of Alexander the Great's army. "Whatever the truth, the first Greek colony on the site was probably destroyed by the Mysians" [29]. Antigonus Monophthalmus, one of Alexander's successors, made a second foundation of the city ca. $315 \mathrm{BC}$ as Antigoneia. "Following Antigonus' defeat and death at the Battle of Ipsus in 301 BC, the city was captured by Lysimachus, who renamed it Nicaea" in tribute to his wife [29]. Sometime before 280 BC, Nicaea came under the control of the kings of Bithynia, and then, along with the rest of Bithynia, Nicaea came under the rule of the Roman Republic in $72 \mathrm{BC}$.
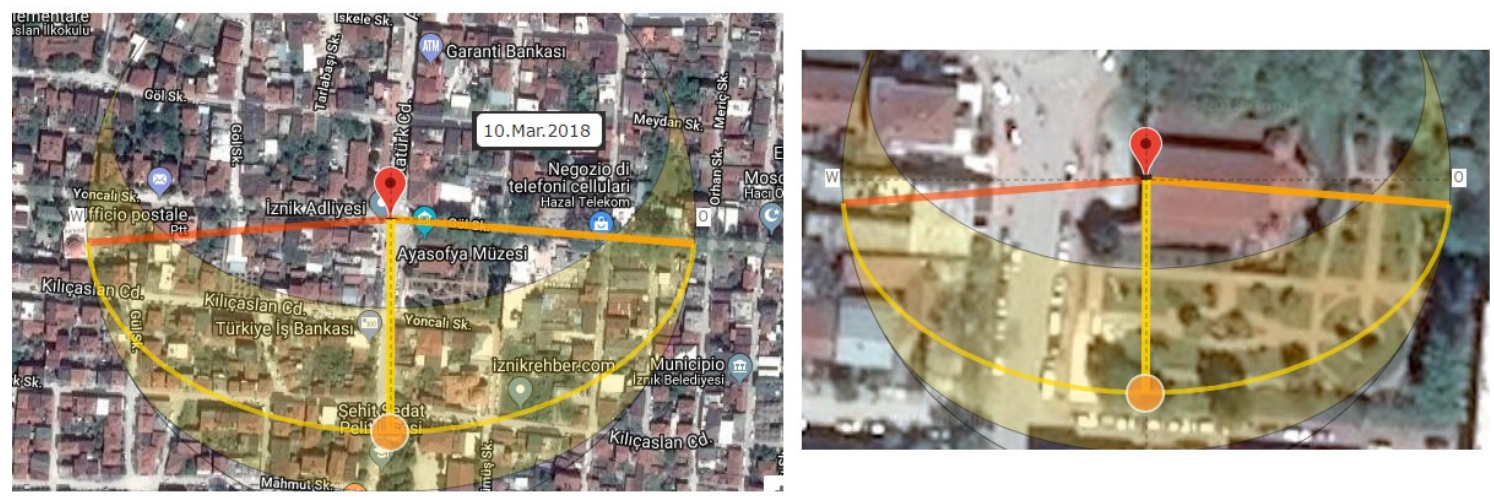

Figure 9: Hagia Sophia in Nicaea.

For what concerns the layout of Nicaea, "The geographer Strabo described the city as built in the typical Hellenistic fashion with great regularity, in the form of a square, ... it had four gates, and all its streets intersected one another at right angles in accordance with the Hippodamian plan, so that from a monument in the centre all the four gates could be seen. This monument stood in the gymnasium, which was destroyed by fire but was restored with increased magnificence by Pliny the Younger, when he was governor there in the early 2nd century AD. ... Emperor Hadrian visited the city in 123 AD after it had been severely damaged by an earthquake and began to rebuild it" [29].

Actually, being the Roman town-planning based on a regular grid of streets, like that used in the Hellenistic period, which was based on the grid plan of the towns proposed 
by Hippodamus of Miletus (498 - 408 BC), it seems probable that Hadrian had maintained the original layout of the streets of Nicaea. In the Hellenistic town-planning, the main streets were the plateiai, the analog of the Roman decumani.

Nicaea has its Hagia Sophia of the Byzantine period. The church was built by Justinian I in the 6th century [30]. It was in this building that the Second Council of Nicaea met in 787. As we can see from the Figure 9, the church has an orientation which is the same of the plateiai (decumani) of the town. A solar orientation is possible, for sunrise on March 10 or October 3, according to the astronomical horizon.

\section{Santa Sofia in Italy}

As told in [2], "The dedication of the Hagia Sophia of Constantinople under Justin II served as a template for the dedication of other Byzantine churches as well as early medieval churches in Italy prior to the Great Schism". And therefore we have Santa Sofia in Benevento built in the 8th century, and Santa Sofia in Venice built in the 9th century. Let us consider them.

By means of suncalc.net we can study the orientation of Santa Sofia in Venice. As we can see from the Figure 10, the church is aligned along the sunrise on summer solstice. Note also that the church has an orientation different from that of the surrounding houses.

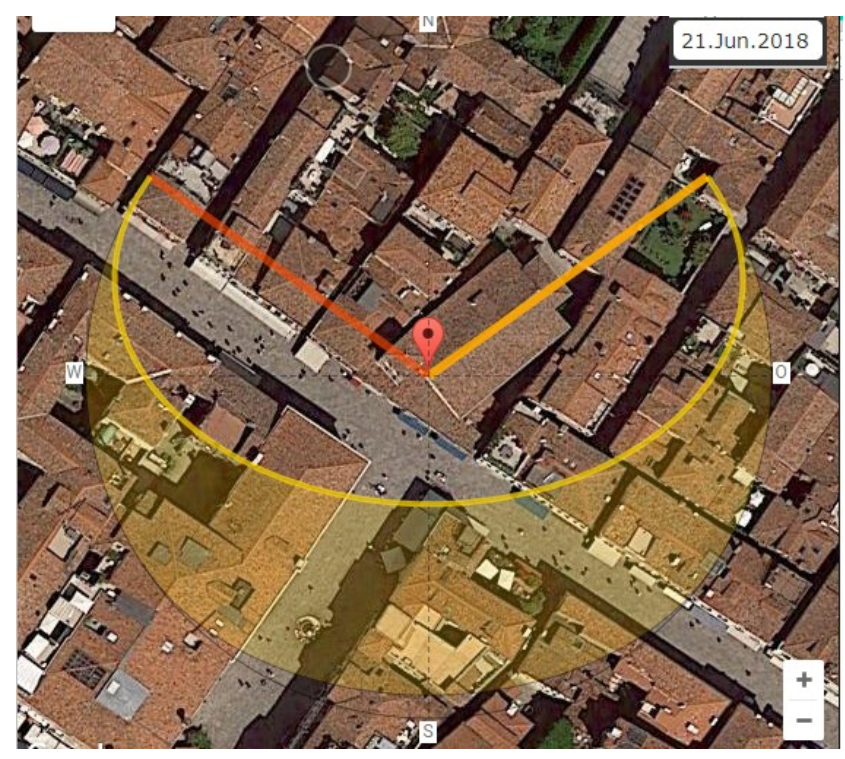

Figure 10: The orientation of the church of Santa Sofia in Venice along the sunrise on summer solstice (Courtesy, suncalc and Google Earth). 
In [31], we read that a wooden church of Saint Sofia in Venice is documented in chronicles from 886. The construction of the church began in 1020, but it was the subject of a major reconstruction from 1507-1534. Then a late-1600s reconstruction was made by architect Antonio Gaspari.

For what concerns the church in Benevento, we learn from [32] that this church is one of the main surviving examples of Lombard architecture. The church was founded by the Lombard Arechis II of Benevento around 760. The edifice was modeled on the Palatine Chapel of King Liutprand in Pavia. After the defeat of Desiderius by Charlemagne, and the consequent fall of the Lombards in the northern Italy (774), Santa Sofia in Benevento became the national church of the Lombards, who had taken shelter in the Duchy of Benevento [32]. Arechis dedicated the church to the Hagia Sophia, like the basilica in Constantinople.

"The church was severely damaged by an earthquake in 1688 and another in 1702 ... Cardinal Orsini, the future Pope Benedict XIII, had the church rebuilt in Baroque style. The restoration work, started in 1705 , transformed the plan from a stellar to a circular one, added two side chapels, and changed the appearance of the apse, of the façade and of the pillars. ... In 1957 most of the original appearance was restored, basing on evidence from historical documentation, with the exception of the Baroque façade" [32]. In the Figure 11 we can see that the church has a solstice alignment.

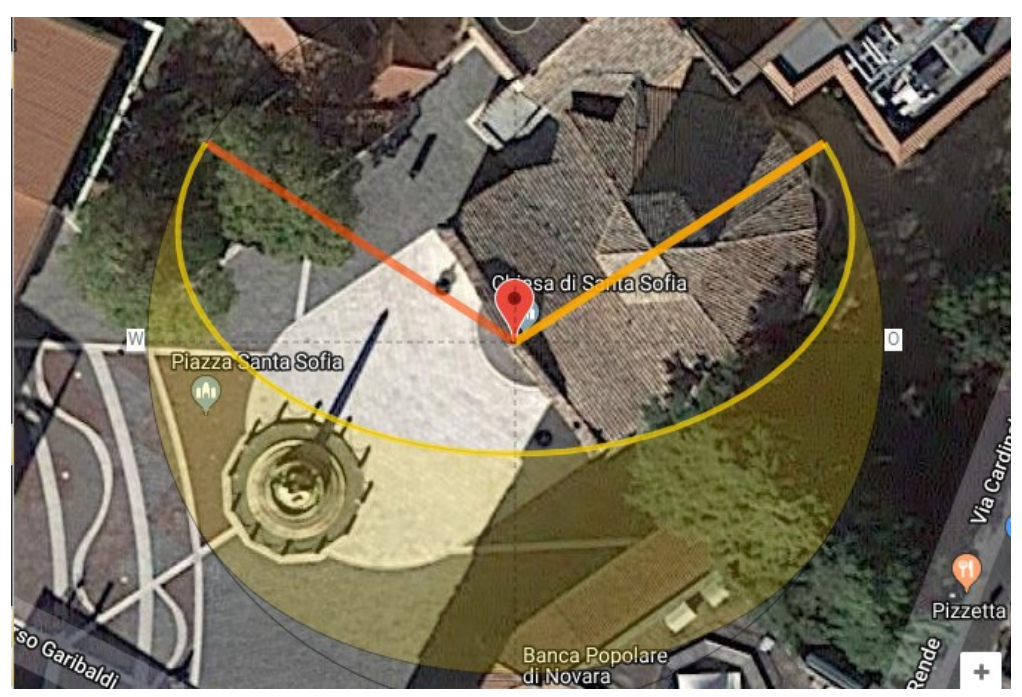

Figure 11: The orientation of the church of Santa Sofia in Benevento along the sunrise on summer solstice (Courtesy, suncalc.org). 
For what concerns the case of Venice, the rii and calli, the "streets" of the town have a regularity which deserve of being investigated in a future work. For Benevento, the Roman town had three main decumani, two of them can be identified with Via Garibaldi e Via Annunziata. Their direction is close to the direction of the sunrise on the winter solstice, and therefore different form the orientation of Santa Sofia.

\section{Discussion}

In this article we have discussed the orientation of some churches dedicated to the Hagia Sophia and built before the 10th century. They had as a model Hagia Sophia in Constantinople. For this church, and for Hagia Sophia of Thessaloniki and Sofia, Bulgaria, we can find a solar orientation. But this orientation is the same of the streets of the Roman town in which they were built. The same is true for the Hagia Sophia in Nicaea, which has the same orientation of the grid of the streets of the town, which is probably the same grid of the Hellenistic period. As a consequence, it is possible that the orientation of these churches was constrained by the local urban planning, and not deliberately chosen by their architects. We have also investigated other churches dedicated to Hagia Sophia, in Venice and Benevento, and also those in Padua, Drama and Nicosia, of the 10th and 11th century. These churches display a solar orientation too. Other churches dedicated to the Holy Wisdom are given in the list en.wikipedia.org/wiki/List_of_churches_dedicated_to_Holy_Wisdom. From the satellite images, it is not easy to determine the position of the apse in the churches, but they do not seems to display an orientation to the direction of the sunrise.

\section{References}

[1] Owen Jarus. March 1, 2013. Hagia Sophia: Facts, History \& Architecture. Live Science, Available at www.livescience.com/27574-hagia-sophia.html

[2] en.wikipedia.org/wiki/Holy_Wisdom

[3] Nadine Schibille (2016). Hagia Sophia and the Byzantine Aesthetic Experience, Routledge.

[4] en.wikipedia.org/wiki/Constantinople\#Before_Constantinople

[5] R. Janin, Constantinople Byzantine. Developpement urbain et repertoire topographique.

[6] staging.doaks.org/research/publications-1/dumbarton-oaks-papers/dop54 
[7] Dallas, T. G. (2015). On the Orientation of Byzantine Churches in Thessalonike.

Mediterranean Archaeology and Archaeometry, 15(3), 213-224. DOI: 10.5281/zenodo.27748.

[8] www.livius.org/articles/place/via-egnatia/

[9] Sparavigna, A. C. (2017). Astronomical Orientations in the Roman Centuriation of Tunisia. HAL 〈hal-01543034〉

[10] Sparavigna, A. C. (2017). The Ancient Norba and the Solstices (January 7, 2017). SSRN Electronic Journal. DOI: 10.2139/ssrn.2895354

[11] Sparavigna, A. C. (2016). Roman Towns Oriented to Sunrise and Sunset on Solstices (May 8, 2016). SSRN Electronic Journal. DOI: 10.2139/ssrn.2777118

[12] Sparavigna, A. C. (2016). The Town Planning of Pompeii and Herculaneum Having Streets Aligned Along Sunrise on Summer Solstice. SSRN Electronic Journal. DOI: $10.2139 /$ ssrn.2802439

[13] Sparavigna, A. C. (2017). The Walled Town of Alife and the Solstices. Philica. Article number 1045, 2017. HAL, hal-01464777

[14] Sparavigna, A. C. (2017). L'antico tracciato urbano di Venafro ed il solstizio d'estate. 2017. HAL, hal-01538368

[15] Sparavigna, A. C. (2017). Two Roman Towns in Germany Having a Solstitial Orientation of Their Urban Planning. Philica. Article 1060, 2017. Available HAL, hal01649826

[16] Sparavigna, A. C. (2017). Wien and the Winter Solstice (January 15, 2017). SSRN Electronic Journal. DOI: 10.2139/ssrn.2899730

[17] Haverfield, F. (1913). Ancient Town-Planning, Oxford, Clarendon.

[18] Barthel, W. (1911). Römische Limitation in der Provinz Africa, Bonn, Carl Georgi Verlag

[19] Sparavigna, A. C. (2015). Roman Centuriation in Satellite Images (December 26, 2015). PHILICA 547. Available at SSRN: https://ssrn.com/abstract=2742223

[20] Campbell, J.B. (1995). Sharing out land: two passages in the Corpus Agrimensorum Romanorum. The Classical Quarterly (New Series), 45(2):540-546.

[21] Fowler, W.W. (1914). Corpus Agrimensorum Romanorum, Recensuit Carolus Thulin. Leipzig: Teubner. The Classical Review 28(03):108-109.

[22] Gemoll, W. (Ed.) (1879). Hygini Gromatici Liber de munitionibus castrorum, Vol.1439. In aedibus BG Teubneri. 
[23] Alexandratos, L. (2007). Studi sugli Agrimensori Romani: per un commento a Hyginus Maior. Tesi di Dottorato, Università di Bologna.

[24] Castagnoli, F. (1959). Centuriazione, in Enciclopedia dell'Arte Antica. Available at the Web site of Treccani, www.treccani.it/enciclopedia/centuriazione_(Enciclopediadell'-Arte-Antica)/

[25] en.wikipedia.org/wiki/History_of_Sofia

[26] en.wikipedia.org/wiki/Saint_Sofia_Church,_Sofia.

[27] Dikov, I. (2016). Bulgaria's Sofia starts excavations of Western Gate of ancient Serdica in preparation for restoration project. May 14, 2016. In Ancient Rome / Roman Empire, Ancient Thrace, Antiquity. Available at archaeologyinbulgaria.com/2016/05/14/ bulgarias-sofia-starts-excavations-of-western-gate-of-ancient-serdica-in-preparation-forrestoration-project/

[28] Pope Benedict XVI (2006).The Spirit of the Liturgy, Ad Solem, p. 64.

[29] en.wikipedia.org/wiki/Nicaea

[30] en.wikipedia.org/wiki/Hagia_Sophia,_İznik

[31] en.wikipedia.org/wiki/Santa_Sofia,_Venice

[32] en.wikipedia.org/wiki/Santa_Sofia,_Benevento 